\title{
The Discrimination of Women in Buddhism: An Ethical Analysis
}

\author{
Archana Paudel, Qun Dong \\ School of Humanities, Southeast University, Nanjing, China \\ Email:paudel_archana@yahoo.com
}

How to cite this paper: Paudel, A. and Dong, Q. (2017) The Discrimination of Women in Buddhism: An Ethical Analysis. Open Access Library Journal, 4: e3578.

https://doi.org/10.4236/oalib.1103578

Received: April 1, 2017

Accepted: April 23, 2017

Published: April 26, 2017

Copyright ( 2017 by authors and Open Access Library Inc.

This work is licensed under the Creative Commons Attribution International License (CC BY 4.0).

http://creativecommons.org/licenses/by/4.0/

\section{(c) (i) Open Access}

\begin{abstract}
Position of women in Buddhism has been debated for a long time. In my article, I will try to figure out the real situation of women in Buddhism. I will discuss something about sexism in Buddhist religion. There seem to be many difficulties that women following Buddhism are facing. I will highlight some of them in my article. I will also discuss the inferiority issues and how women are perceived as an inferior being in Buddhism. I will focus on the birth issues in Buddhist culture and religion in my article. I will be talking about how the birth of a woman is considered in Buddhism. I will also talk about the difficulties women are facing following Buddhism. In this way, I will try to explore the room for women in Buddhism in my article.
\end{abstract}

\section{Subject Areas}

Philosophy

\section{Keywords}

Buddhism, Ethics, Bhikshu, Bhikshuni, Female Birth, Sexist Religion

\section{Introduction}

We are now in the twenty first century. In today's world, women have been competing with men in all the fields and have been excelling in all the fields. Today, we can find that women have reached to positions such as head of the state. We can take examples of Germany, Nepal and many other countries in this regard. Today, CEOs of big organizations are women. There has been a sense of equality in both men and women. This is in fact very good news. This shows us how things have been changing in the modern days. This will give equal opportunities to both men and women. The country can also develop very fast if everyone gets good opportunities. Men and women are considered the two wheels 
of a cart. They should be considered equal if we want the cart to move ahead. If one wheel is smaller than the other, the movement will definitely be impaired. This is completely different as compared to the ancient times. The example of this can be seen from this article which I found in a website named Buddhist studies, 2008. In ancient India, the position of women does not appear to have been a very happy one. Generally women seem to have been looked upon as being inferior to men. At times they were considered as being on the same level as the Sudras, the lowest of the four castes. Their freedom was extremely limited. The general view appears to be that they had to be under the care of parents in their childhood, under the protection of husbands in their youth; and in their old age they had to be under the control of their sons. Therefore, it was thought that they do not deserve any freedom. Their main role was considered to be that of housewives, managing the affairs in the house according to the wishes of their husbands [1]. This shows how inferiorly women were treated at that time. It seemed that the society did not put any value on the existence of women at that time. We have been listening to stories since our childhood that if her husband dies, the women had to kill her by jumping to the funeral which has been widely known as "Sati Pratha". Whenever I listened to such stories, I always used to think that why only women and not men in such cases. I used to be surprised by the injustice that the society had been doing to women. My heart used to be very heavy whenever I listened to such stories. Then I used to think that this was in the past. Things have changed to a lot of extent at present times. I used to be somewhat relieved. Now, when I look at the present time, I feel that definitely things have changed as compared to the past but not to the extent that I had imagined. Women today are still not considered as equal to men, be it as compared to strength, education or social status. This male dominated society has still not considered women to be at the same level as compared to men. Women still have miles to go before they can fill this gap of inequality. The situation is better in the western world as compared to the east.

\section{Is Buddhism a Sexist Religion?}

At times questions have been raised about Buddhist religion as being a sexist religion. Many instances have proved so as well. I personally think that sexism is a little favored in Buddhism. This can be seen by the behavior of Gautam Buddha himself. We have read in articles that Buddha himself was reluctant to take women as nuns. He was afraid of the various consequences that would arise if women were enrolled. The consequences he thought would have a negative impact on the society. It was only upon the request of his stepbrother and assistant Ananda, Buddha agreed to take female followers into the Sangha. Mahaprajapati Gotami, maternal aunt of Buddha was the first women allowed to enter the Sangha. Even though they were allowed to enter the Sangha, they were ordered to follow the eight garudhammas, the eight weighty restrictions which only applied to them and not to the male followers. These eight restrictions clearly kept bhikkhus at a much higher level than the bhikkhunis. I think these eight restric- 
tions made Buddhism a kind of sexist religion. Women are not considered as a complete entity in Buddhism. Their body is not considered fit to attain enlightenment and become Buddha. There is a concept that women are not complete until they attain enlightenment to become reborn as a man. It is clearly stated in the Bahudhatuka-sutta that there could never be a female Buddha. As Prof. Heng Ching Shih states, women in Buddhism are said to have five obstacles, namely being incapability of becoming a Brahma King, Sakra, King Mara, Cakravartin or Buddha [2] [3]. Only women are to follow the eight weighty restrictions is very biased in my opinion. This further strengthens the sexist view in Buddhism. This clearly views women body as an incomplete and men form is required for the completeness. The psychological impact that women had with this view is a great one. This kept them in a weaker and inferior position. They thought that they were incapable of doing things. This pushed their moral down. Shaw has explained about this psychological impact in his article. He says that this belief had negative implications for women insofar as it communicated the insufficiency of the female body as a locus of enlightenment [4]. According to Ajahn Sujato, the early texts state that the most severe of the garudhammas, which states that every nun must bow to every monk, was instituted by the Buddha because of the customs of the time, and modern scholars doubt that the rule even goes back to the Buddha at all. They think that the rule may have been formulated later. It can be a possible argument because the rules were written only after the people started to become literate. In the ancient times, we know that men were the first ones to become literate. It was only much later that women got the chance. So, it is possible that these rules were written by a male dominant society. We can assume that one who is in power will definitely write down the rules that will favor that group. Men may have written the rules so as to show their superiority as compared to women. Furthermore, an identical rule is found in Jainism. Some commentators on the Aganna-Sutta from the Pali Canon, a record of the teachings of Gautama Buddha, interpret it as showing women as responsible for the downfall of the human race. This view can be a topic of a lengthy discussion. I think that it is not the women but the desires of men that has resulted in such a downfall. My view finds its place as Buddhist interpretation also shows lust in general, rather than women, as causing the downfall [5].

A very surprising rule as I would say is that a nun should behave respectfully towards a junior bhikshu and vow down in his respect to greet him, no matter how old she is. This clearly shows the sexist aspect of Buddhism. It clearly shows how females have been placed at a lower position as compared to males. I think that a society can only move forward when the women's living in the society are shown due respect. The society should understand that women can come out in three forms in the society. She is at first a daughter, later a wife and then a mother. Men can never come in these forms. It is the women who create a society. Can men give birth to a child? The answer definitely is never. It is the women who keeps the child in her body for 9 months and ultimately gives birth. 
She is the first teacher of a child. Despite all these facts, women are suppressed in terms of equality and rights. It is not only in Buddhism but in all the religions that are being followed throughout the world. In Buddhism, a female nun has to follow the eight Gurudharmas, which are known as very strict rules or the monastic etiquette. There are no such rules for the male monk. Buddhism says that a bhikshuni should seek her higher education from the bhikshus. Why cannot a bhikshuni who has already got higher education train other junior bhikshunis? If a bhikshuni has acquired the same level of education as that of a bhikshu and is capable of delivering it as a bhikshu does, then why can't she be the knowledge giver? Analayo quotes this biased view in her article in this way: [You], named so-and-so, after a woman has received the going forth and the higher ordination from the bhikșus, she should fully understand that she has become a bhikșuni [6] [7]. The article further states that a bhikshu can ordain a female nun even in the absence of qualified bhikshunis if there is a situation of such kind. This definitely raises a question that if such things can happen then why not the opposite of it is also possible. Bhikshus are given the right that if no bhikșunis are available, the brahmacarya and bhikṣuni ordination ceremonies may also be performed by the bhikșu sangha alone. Based on the first gurudharma, bhikșus can give all stages of a woman's ordination, starting with the going forth and reaching all the way up to the higher ordination, if circumstances require. But, even if the circumstances require, bhikshunis are not allowed to do so. When we see such kinds of opinions in Buddhism, we definitely feel to raise one question: Is Buddhist a sexist religion? The answer that comes to my mind is that to some extent yes it is a sexist religion.

\subsection{Birth of a Woman in Buddhism}

This issue is a very interesting issue as far as Buddhism is considered. Birth of women has not been considered to be a good sign in my opinion. Women birth has always been taken negatively in my opinion. Let us consider Thai Buddhism in this regard. It is considered in Thai Buddhism that women are born from their bad karma. How can karma decide the sex of a fetus? This is a very strange opinion in my view. Women are made to believe that their body is the result of bad karma they had done in the past. One of the researchers has done a lot of research in this regard. He writes that many women are convinced that they carry a heavy load of negative karma due to the simple fact of their gender. Thai women seem to accept their suppression without complaint [8]. This shows that if you insist something continuously for a long period of time, the other person may start to believe that the real situation is the same as insisted. An example of this can be that if someone is repeatedly accused of being out of mind, he will one day start to think in this regard and if many people say so, he will slowly accept this. The women form is never considered a complete one until and unless she takes rebirth as a man. Testimony to this notion can be found in a 14 thcentury inscription from Sukhotai, where the queen mother formulates an aspiration that the merit of her founding a monastery may conduce to her rebirth as 
a male [9]. This shows how birth as a male is valued in ancient times. In a patriarchal society like ours, women come across so many restrictions. They are always made to feel that they are under the power of a more supernatural thing, which is the man. They feel so many restrains in the society and this may be the reason why many women have expressed their dissatisfaction of being women and have expressed their willingness to become men in their next birth. A rationale for this type of aspiration finds expression in a passage in the commentary on the Sutta-nipāta, the Paramatthajotikā, which reports an aspiration made by a woman to be reborn as a man. In her aspiration, she notes how disgusting it is to be a woman and says that even the daughter of a wheel-turning monarch will be under the control of others and therefore aspires to become a male. The story then continues by reporting that she was indeed able to overcome the fruition of the previous evil deed (pāpakamma) that had caused her to be born as a woman and with the power of her present meritorious deed and aspiration was eventually reborn as a male devaputta. This story has been cited by Analayo B in her article. Having a look at such stories shows how females have been suppressed in the society. They seem to be tired of such gender differences issue. They want to be reborn as a more supernatural creature, the man. They have the feeling that once been born as a man, they don't have to come under the control of anything and can live their life as a free human being.

Having talked so, I would like to talk on something that is prevalent these days. It is nothing but the operations that are being undertaken these days to change the sexes: that is male becoming females and the females becoming males. Sex change operations have been so common these days. In today's world, we hear a lot about such kinds of operations. Men desire to become women and women desire becoming a man. Thanks to the advancement of science and technology which has made all this possible. I am not discussing the merits and demerits of such operations in my article which will indeed take my article far outside the topic I just want to relate this to that of the ancient times where sex change operation was not possible. Had it been possible, much would not have been talked about the female desire to be born as a male in the next birth. In ancient times change of sex by women was considered to take them out of bad karma. I really don't have much idea about the change of sex by women of today. I am really unaware as to why they are doing such operations these days. May be I can read a lot of articles written by women undergoing such operations to find out the real cause. Let's forget that right now. Further support of bad deed turning into a women and a good deed making a man can be seen in this story in Dhammapada. The story goes that, on seeing the beautiful skin color of the bhikkhu Mahākaccāyana, Soreyya had the wish to have him as his wife or else that his wife might have a similar bodily hue. This impure thought caused him to change into a woman right on the spot. The tale continues with his experiences as a woman until at some point he offers a meal to Mahākaccāyana and asks to be forgiven, whereupon he becomes male again. We have heard several of such kinds of stories from our ancestors that if a man cheats his wife and goes to 
other women, he will go to hell and for hundreds of birth be a women whereas if a woman does good work and leaves her desire to be a woman again, will be reborn as a man. These are merely stories told and heard. Let's not get into the authenticity of these stories. In the canonical account there is no indication that for the bhikkhu to become a female is the result of bad karma, or that for a bhikkhuni to change into a male is the result of good karma.

\subsection{Difficulties Faced by Women in Following Buddhism}

This is a very big topic and can be a single topic for an article. I will not get into much detail about the difficulties a women faces in following Buddhism. One of the chief difficulties lies in the female ordination. Female women in order to become a Buddhist should have observed a two year training period as a probationer-a sikkhamana. After having observed this period of training, higher ordination should be requested by her from both communities, that is, from the communities of bhikkhus and bhikkhunis. Initially, this created a big problem as the females were very much ashamed to answer questions regarding their genitalia and menstruation from the bhikkhus. This kept them in a very awkward situation. Later on, having acknowledged this problem, Buddha ordered that bhikkhus should ordain those candidates who have already been formally interrogated by a community of bhikkhunis. This rule provided some sort of relaxation to the female candidates as talking into these matters with a bhikkhuni was much easier and comfortable for them.

The three forms of Buddhism have different principles. Ordination of bhikkhunis in one community may not be acceptable in another community. This is a very serious issue. I personally think that this issue should also be resolved. Suppose a woman who wants to become a bhikkhuni takes the Chinese Dharmaguptaka ordination and subsequently wears their style of robes and participates in their monastic rituals. Traditionalists would probably have little to object; only they would not recognize her as a Theravāda bhikkhunī. The problem is not merely that a woman wants to become a bhikkhuni. The question is rather if a bhikkhunī, who has been ordained in the Chinese Dharmaguptaka tradition, can become a recognized member of the Theravāda community as stated by Analayo B [5]. This is a legal issue in my opinion. It takes a lot of time to resolve such legal issues. It is not a matter days. In my opinion, there should be a worldwide rule which can be followed anywhere in the world. Religion should not be tied to the boundaries of a nation.

It is true that the gurudhhamas have placed bhikkhunis in a lower position compared to bhikkhus. In Buddhism, there are several rules that should be followed by a bhikkhuni and not by the bhikkhus. These rules also clearly put women in a lower position as compared to men. Nowadays, we talk a lot about equality. Lots of seminars are being held throughout the world stressing this matter. But on the grounds of reality, I think nothing much has been achieved. Everywhere in the world, women have been taken as a dependent body, which have a solid identity when men stand by their side. Be it politics, sports or any- 
thing. We cannot only blame men in this regard. Women should also rise up to prove their identity. They should build in confidence in themselves. A strong determined woman is what we are looking in today's male dominated society. In the past, it was thought that active male was a good thing whereas passive male was considered a bad thing. On the contrary, passive female was considered good and active female was considered bad. This opinion in itself is very strange and must be changed now.

There are difficulties but women have not given up. There are various examples of female nuns helping other needy female nuns. It gives a lot of pleasure to see one human being helping the other needy ones. This will help to raise the living standard of those who are living below average standards. One of the examples is of the nuns from the Daxingshan nunnery in Taiwan. They held a bhikkhunī dāna ceremony on October 5, 2010 where approximately 2900 nuns of all three monastic statuses attended the dāna ceremony. The nuns were fully sponsored to attend this ceremony. The main motive was to help the other counterpart needy nuns [10]. Sri Lankan bhikkhuniss became the first recipients of this ceremony because of their close connections with Chandima Thero. When Daxingshan Nunnery expressed the wish to found a bhikkhuni academy in Sri Lanka, Chandima Thero was more than happy to provide the necessary land. Within two years, a Buddha Hall, a lecture building and a hostel were built. The construction was completed in July 2012. All expenses were paid by Daxingshan Nunnery. Additionally, Daxingshan Nunnery also pays the cost of running the training program, including staff salaries, food and lodging for the nuns, utility bills, etc. Realizing that education is the only thing that can bring an up liftment of people in the society, the nuns having all levels of education are included as far as applicable and enrolled to provide them with higher education. This has helped to educate the nuns and help them establish their own identity in the society. Another example of such an effort can also be seen in Nuns Foundation in Nepal which was established by Anni Choying Dolma. She is popular in Nepal for her songs. This foundation has many nuns who are supported by the foundation for their education. They are provided with free lodging and food. The main purpose of the foundation is to produce a nun who is independent and capable of handling with all the circumstances in the society. These examples show that the agency for empowerment did not begin from without but from within. These nuns are creative for taking the initiative to break the cultural conformity unfavorable to Buddhist nuns and create a situation enhancing their educational opportunity.

\subsection{Female Inferiority in Buddhism}

Feeling of inferiority adversely affects the development of an individual. It totally interferes with the progress of an individual. Not only the one feeling inferior is affected, but also the one bringing others into this situation is also affected. State of mind plays a significant role in all the decisions we make. Taking someone as an inferior being is also our state of mind. If we can come out of this state of 
mind, then we are out of such inferior issues. Female inferiority issues are not a new one in Buddhism. Several times questions have been raised of such issues and several attempts have been made to clarify such issues. Sometimes, I think that it is not the religion that makes someone superior or inferior but it is their followers who have interpreted the religious materials as to their benefit which makes someone superior than the other ones.

Talking about the present day status of women in Buddhism, it can clearly be seen that nuns are placed at an inferior positions as compared to monks. They should speak after the monks have spoken, eat after they have eaten, sit behind the monks in rituals and ceremonies, and cannot hold the highest positions in any ceremony and many more. One of the Gurudhhamas which states that even a senior nun should bow down to a monk who has just been initiated shows how inferior the women have been placed in Buddhism. As already stated, it is said that a female nun can never become a Buddha though she can become an arahant. Very few times, questions have been raised about this inequality and when raised though, have been suppressed by the large number of people who still believe that women should be placed at an inferior position as compared to monks. Even in Taiwan, where nuns status is highest, and where nuns and laywomen far outnumber monks and laymen, only two leaders of orthodox Buddhist sects, Master Yin Shu and Master Xing Yun of Buddha's Light International, have publicly rejected part of the Eight Garudhammas and other rules and teachings that imply that women are inferior to men and should be treated as such. Few other Buddhists in the country have made such public statements, or given vocal support to equal rights, opportunities, or status for women [11]. In many cases, women themselves have deep rooted feelings that they are inferior to men. They think that they cannot be in the same place as men are because they are more jealous, short tongued, evil, weak, vain, and ignorant and so on. This also makes it difficult to bring out this deep rooted feeling in women and establish a level of confidence in them. During his research, Goodwin found that this concept is changing very rapidly in Taiwan, especially in the young generations. They do not hold these negative views any more. There is also a growing consciousness within the Buddhist community that these negative teachings and unequal rules should be abandoned. This shows that the number of people supporting equality is on the rise. I think Dalai Lama's effort to eliminate the discrimination of nuns should also be mentioned here. He says that this discrimination causes harm and should be abandoned. He has advocated that reforms should be made. We come to see that Tibetan Buddhism has moved forward in this context. Many of the Tibetan leaders have expressed a desire for improvement of the current conditions.

In the west, I can say that the situation is a bit better. Half of the teachers and leaders in western Buddhism are women. In the west, many view that Buddhist men and women are equal. They get equal opportunities. In Asia, however things are yet to change. The nuns here receive less education, respect, training and material support as compared to the monks. They have very little or no 
chance of advancement. In some of the countries, women are barred from entering shrines or temples. Not only so, even a monk who supports women of ordination may get severe punishment which can even result to his expulsion. This is a clear illustration to show that things are yet to be changed. In India, the inferior views of women were established even before the time of Buddha. It was there at the time of Buddha and even later and to date. This may be because of the fact that men have been able to gain higher positions in the society as regards to politics and have influenced the compiling, editing and interpreting of the religious doctrine. Scientifically saying, the male hormone testosterone also plays an important role as it increases the men's desire of gaining a status. There are stories from Buddha's time and thereafter praising the female nuns for their intelligence, capability and hardworking nature. They have even described them as competent and efficient as male counterparts. Buddha was very reluctant to ordain women. He refused to ordain his aunt Mahaprajapati three times and only ordained her after Ananda, his stepbrother and follower requested him to do so. He thought that women would infect and destroy any religion they entered. $\mathrm{He}$ thought that ordaining a woman would reduce the life of a sangha by half. As an example he said that if the life of a sangha was 1000 years before women were administered, it would be reduced to 500 years after their administration. This view of Buddha has not been found to be as promising as women have played a vital role in spreading Buddhism throughout the world. In some of the countries, there are only women who have been handling the monastics very well. Not only in Buddhism, we can take examples of other religions as well. Protestant Christianity, non-Orthodox Judaism, Hinduism, Jainism, Sikhism, Shintoism, and Daoism have all shown no signs of weaknesses by including women in their religion. Instead, we can say that women have played a pivotal role in all these religions.

Many researches have been done in the past and all of them have shown that inferiority issue leaves a greater impact in the society for a long duration of time. Worthy to mention is the research done by an elementary school teacher named Jane Elliot in 1968. Elliot tells her third grade students that blue eyed people are better than brown eyed people, more civilized, cleaner, and smarter. She points out undesirable behavior in the brown-eyed people and implies it is evidence of their selfishness, jealousy, lower intelligence and abilities, bad temper, negative influence on others, and other unflattering traits. She then institutes several undesirable rules to the brown eyed people and tries to constrain them. What she found was really interesting. Even in third grade students, she noticed that after imposing such rules, the classroom is easily transformed. The blue eyed children begin to view the brown eyed ones as inferior to them. Some of the children tried to avoid them, mock them or treat them abusively. She found that some of the children were reluctant to accept this bias but there was only one child who raised a voice against this discrimination. She found that the brown eyed children were hurt, angry, and dejected. A few misbehaved or fought with other children. The brown eyed children also had difficulty in concentrating and per- 
formed worse than usual on a timed vocabulary test, whereas the blue eyed children performed better than usual. The next day, the teacher announced that she misled the class the previous day. It is in fact brown eyed people who are superior and immediately the rules, views, and dynamics switched. On the second day it is the superior brown eyed children who tested better than usual and the inferior blue eyed children who performed more poorly than usual, and who experienced the same adverse effects felt by the brown eyed children the previous day.

In this example, the teacher can be taken as an authority that imposes rules and regulations and the children as the followers of such rules and regulations imposed by a senior authority without any hesitations. The research found that the act of making someone superior than the others had an effect, not only on the ones who were inferior but to the whole class. Elliot describes this behavior in this way: "I watched what had been marvelous, cooperative, wonderful, thoughtful children turn into nasty, vicious, discriminating, little third-graders in a space of fifteen minutes". This is only one of the examples of how inferiority feeling can disturb the whole system. We can correlate this with Buddhism where women are taken as inferior ones as compared to their male counterparts. Many of the women followers have deep rooted feeling that their body is an impure one and they cannot become Buddha. For that they need to transform themselves into a male body and wish to be reborn as a male so that they can become Buddha in their next life. In most of the cases, women are viewed as a dependent body that need parents or husbands to protect them as they are considered to be weak ones. Men, on the other hand are considered to be strong, protective and bread winners of the family. Women are still viewed as polluted ones because of their menstrual blood. Even the younger and the old ones are not spared. The younger ones are thought to be polluted later and the older ones have already been polluted. Women are always considered in a lower position, secondary to men. The rising number of abortions in developing countries is an example of how females are taken in our society. A daughter is killed even before she is born if the parents come to know that the upcoming child is a daughter. Recent advances in science and technology such as ultra-sonogram has made it possible to diagnose a fetus in the womb. This is very common in the first birth. In later births, this is not such a bigger issue. Things have changed in the recent times but not much. Nowadays, we can find women who are very independent and earn far better than their male counterparts. Parents are happy to give birth to a daughter child. Some parents hope to have a baby daughter as their first child. This is indeed a very good sign. They view that daughters are more caring as compared to sons. Some even view that a son gets farther away from parents as he is married but a daughter gets even closer to her parents after her marriage. According to the latest (2009) U.N. Human Development Program (UNHDP) Gender Empowerment Measure Report, only one Buddhist majority or former Buddhist majority country, Singapore, was among the top fifty member countries ranked on the basis of best overall gender equality. 
We know that Buddhist dharma teaches us that all are equal. It teaches us that if one harms others, they are also harmed indirectly. So, those who look down on women as inferior or treat them unequally will also be harmed in one way or the other. So, we can say that those who treat others unequally or harm them, their karmic burdens will be heaviest. Discriminatory treatment and concepts instill beliefs that in turn affect behavior and achievement. Sometimes people are taught to treat a group as inferior to other group but they do not realize that in doing so they are not only harming that group but are also harming themselves. In Buddhism also, such kind of inferiority persists even till today. Women are still perceived as being inferior to men. Viewing others negatively or as inferior, or otherwise discriminating against them, is harmful. In the Maha Assapura Sutta, MN 39, the Buddha cautions his followers not to exalt ourselves or disparage others. In the Sutta Nipata and the Samyutta Nikaya, he asserts that one should not construe views, knowledge, spiritual paths, practices, oneself, or others as superior, inferior, or equal as to do so is to grasp at perceptions and views. Scientific and social researches have proved that discriminatory treatment and views are unskillful, unwholesome, blameworthy and unwise and when adopted and carried out will lead to harm and suffering. This doesn't give a positive impression.

The rulings given by the Buddha on bhikkhunī ordination in the Theravāda Vinaya result in altogether four promulgations:

1) "A probationer who has trained for two years in six principles should seek higher ordination from both communities" (CV X 1.4).

2) "I authorize the giving of the higher ordination of bhikkhunīs by bhikkhus" (CV X 2.1).

3) "I authorize the giving of the higher ordination in the community of bhikkhus for one who has been higher ordained on one side and has cleared herself in the community of bhikkhunīs" (CV X 17.2).

4) "I authorize the giving of the higher ordination through an experienced and competent bhikkhunī as messenger"

From the perspective of the Theravāda Vinaya, this was indeed the proper procedure. There is one story where Mahinda and his bhikkhus could not just confer the higher ordination on the queen and her followers, since in India an order of bhikkhunīs was in existence. This is why the queen and her followers had to wait until Mahinda's sister Sangamittā and her group of bhikkhunīs had come. (CV X 22.2) [12]. This shows that bhikhhunis had been given a place in ordination of other bhikkhunis and their presence was a must for the ordination to take place.

Thailand took a step forward in this regard. In 2003, a Thai Senate Select Committee advised that the 1928 ruling forbidding ordination for women was invalid, as it contravened the Thai constitution's principles of freedom of religion and non-discrimination against women. The Thai National Bureau of Buddhism rejected this advice. However, until recently, the Sangha Supreme Council has not publicly commented on the bhikkhunī revival in Thailand. When female 
aspirants have sought bhikkhunī ordination outside Thailand, most notably in Sri Lanka, their ordination is not regarded by the Thai Sangha Council as pure Theravāda and thus is rendered inauthentic. One step has been moved ahead but it still shows that more steps are yet to be taken. Another example is that of the status of mae chis in Thailand. On an institutional level, the ministries of the Thai government disagree over the status of mae chis. The Department of Religious Affairs classifies mae chis as laywomen. They do not receive government subsidized medical care or education like the monks. Moreover, they are excluded from census data and absent from official records. Here we can see the two sides of a female facing problem in Buddhism. Bhikkhunī and mae chis are two categories of Buddhist female asceticism, one reaching back to the Buddha's time, the latter a Thai creation. Battaglia has done a lot of research on mae chis. One of her interviews with a mae chis is quoted here: I don't agree why we have to fight for bhikkhunī. There is no need to get that high. No need that we have to compete with the monk. Women still give respect to [the] monk. They are superior. It is nature that masculine is more superior to feminine. This is nature. Why [do] we have to strive to make a big fuss of it? We do our own beauty. Buddha's instruction that a woman should seek upasampadā (full ordination) from a dual Sangha, that is, from both the bhikkhuni Sangha and the bhikkhu Sangha. In Thailand, feminism and demands for women's human rights are typically regarded as egotistical and aggressive, and are consequently viewed with suspicion [13].

Taiwan has always had a large number of nuns and those nuns have always been engaged in charitable works, meditation, and teaching. This has paved a way for the equal dignity and equal standing of Buddhist women. One of the twentieth century's success stories with regard to this issue has been the revival and strengthening of the nuns order in South Korea. Korean nuns enjoy one of the highest statuses among East Asian countries, second only to the nuns of Taiwan.

Buddhist organizations founded and run by Buddhist nuns in Taiwan typically interpret Buddhism in a social-activist vein. Influenced by an important reformist line of Chinese Buddhist thought called "Buddhism for the human realm” (renjian fojiao) as stated by DeVido, organizations like the Ciji Compassion-Relief Foundation and the Luminary Buddhist Institute consider the relief of illness and promotion of health to be a part of their Buddhist mandate. Social constraints forced laywomen and nuns into relationships of collusion and mutual need and created a situation in which nuns were more likely than their male counterparts to engage in the healing arts.

But, when we talk about the healing arts, the Buddha ordains that it is unacceptable for nuns to make their living by means of medical knowledge. The same rule he says is valid for the monks as well. Monks are prohibited from providing abortifacients, fertility drugs, or birth control to women. Even though, both the nuns and monks are forbidden to engage in healing arts, we come to find that the nuns are made a special focus of such rules and that they are punished more 
severely than monks for engaging in worldly forms of knowledge. This also gives some light into the inferiority issues. Langenberg argues that the punishment module suggest that the nuns were more likely than monks to be drawn into functioning as healers in the lay community [14]. The consensus of the ancient monastic lawgivers is that monks and nuns should avoid involving themselves in publicly learning, practicing, or teaching outsider lore, including the medical arts.

Another example of a positive step can be taken as that of Srilanka. The Sri Lankan Theravada Buddhist order of bhikkhunis, or fully ordained nuns, was revived in the late 1990s after a gap of circa 1000 years. Sri Lankan government and the bhikkhu sangha have not yet formally accepted the revival. Consequently, although it is legal to hold bhikkhunī ordinations and establish bhikkhunī temples, these temples receive no government funding, making it especially hard for nuns to get a monastic education. Opponents of the bhikkhunī revival thus argue that all Sri Lankan nuns are really Mahayana nuns and should not receive formal recognition by the government or monastic authorities. A step forward has been taken but there are still miles and miles to go before such inferiority issues can be solved. The government has not recognized the ordination but the general public show a lot of love and respect to the nuns. They are always willing to support the nuns. Mrozik quotes such love and affection by giving an example of laywomen donating 3 panties to nuns [15]. Donating such things is considered to show an ample love in their regard. The laywoman says that it is a secret and should not be told but had only told this to the author. Even when love is present, they are also aware that love can quickly turn into something else when expectations are not met. Love is, in fact, quite fragile. The fragility can be easily seen when demands and expectations rise high. Boys take an opportunity when they are provided with greater facilities than that of girls. Those who are not suited to a monastic lifestyle ordain and subsequently disrobe during or after their university educations. Ironically, gender privilege is a double-edged sword for monks. They have many more opportunities than nuns to pursue higher education and develop professional careers, but these very opportunities may push them into a monastic career for which they are not suited and/or make them vulnerable to lay gossip and criticism.

When we talk about the inferiority issues in Buddhism, I think that we should not forget the greed factor. Greed is one of the various factors that has caused Buddha to change the rules of sangha from time to time. Buddha made many rules as he came across various situations. Greed causes problems not only for the relationship between the sangha and the laity, but also for the harmonious functioning of the sangha itself. Buddha made many rules as he came across various situations. One example can be taken as the ability of monks and nuns to manipulate their detailed knowledge of monastic discipline in order to engage in unethical behavior, requiring the Buddha to promulgate one new rule after another, pertaining to ever-more-specific situations seems to be a common theme of Vinaya literature. This shows their greed of having better therapeutic 
knowledge and utilizing it in order to get personal benefits. When we talk about the issues of greed, the name of one nun comes to our mind: Thullananda. We can have a series of discussions as to say whether she was a greedy nun or not. That will take us far away from the topic. For this time, let us only consider the personal favor issues and Thullananda. Thullanandā's personal favoring of some people over others is shown to lead inevitably to all kinds of problematic behaviors, such as unfairly depriving well-behaved monks of alms-food, concealing other monastics' offenses, and violating legal actions that have been taken by the sangha. Like greed, this favoritism is deleterious to both the individual monastic and the smooth functioning of the community as a whole [16]. This behavior of Thullananda made the monks feel that they were inferior to the nuns because she favored nuns a lot and the monks were sometimes deprived of many good opportunities. This is only one of the examples to show that inferiority issues can have a very harmful effect to those directly or indirectly associated with it. Here the monks suffered whereas in other cases, in general the nuns are the sufferers.

After achieving enlightenment, the Buddha began to admit people to the Order based on their own choice so that they could devote their lives to the Path he discovered. This went on for some time until his own father, Suddhodhana, made a request that "in future no boy be admitted to the Order without the permission of his parents". The need to protect his followers should be the exact reason why the Buddha made the spousal consent compulsory for would-be nuns and parental consent for both would-be monks and nuns [17]. This point can also be argued as a matter of female suppression. Buddha has made spousal consent necessary for would be nuns but nor for would be monks. In a male dominant society like ours, the husband is the bread owner of the family in most of the cases. Now, if the husband wants to follow the path of Buddha, there is no need for him to take any consent from his wife. Then the only bread winner of the family is gone. What about the sufferings of the rest of the family? They will definitely die of hunger as they will have no one to support them. The female members of such families are not well trained to take any jobs and it is not easy for them to find a job. In my opinion, female consent should also be made compulsory as it should the females to decide whether to send their husbands or not and in case they send them, what steps can they take so that they do not have to die of hunger.

Buddhism teaches that much of our suffering is a result of attachment to the non-existent self. Despite this, gender has become the supreme organizing principle of traditional Buddhist institutional life. Although the most commonly invoked "slogan" is that the enlightened mind is neither male nor female, Buddhist monasticism finds it very difficult to enter into the dialogue of transforming gender bias and of granting nuns full ordination in the Tibetan traditions, clinging stubbornly to the existing gender hierarchy. Buddhist nuns in the Chinese tradition flourish in China, Taiwan, and Hong Kong because they have access to bhikșuṇi ordination and benefit from a full monastic life. Many ecclesiastics 
maintain that it is the bhikșus rather than the bhikșuniss who represent the concluding authority on the full ordination of nuns. Chödron, in Mohr \& Tsedroen state that Tibetan scholars are currently engaged in research and discussions concerning three possible methods of establishing bhikṣuṇī ordination for Tibetan nuns: 1) a ceremony consisting of ten Mūlasarvāstivāda bhikṣus and twelve Dharmaguptaka bhikṣuṇīs; 2) ten Mūlasarvāstivāda bhikṣus performing the ceremony alone; or 3) ten Dharmaguptaka bhikșus and ten Dharmaguptaka bhikșunīs conducting the initial ceremony. Haas says that the Dalai Lama has specifically requested Western women to spearhead this task, leading to the establishment of The Committee of Western Bhikșunīs/The Committee for Bhikșuni Ordination in the Tibetan Buddhist Tradition in 2005. The Karmapa has gone further than the Dalai Lama, announcing that he is willing to take the first step in ordaining nuns as bhikṣunī [18]. Miranda Shaw concludes that people who pronounce upon the inferiority of women are generally monks who have built up a psychological resistance to women. Buddhist monastic life offers women alternatives to conventional domestic roles and affords them the opportunity to realize their spiritual potential unencumbered by the stereotypes, burdens, and responsibilities of lay life.

Exercises that concentrate on breathing are, in short, simple ways to bring the perspective of the meditator back to a basic reality of life that can often be lost. Having an insufficient understanding of self and the lack of self-identity, according to Irigaray, means that there cannot be proper respect for the other. If there is no space between self and other, there is always a danger of invasion or appropriation of the other. On the contrary, Buddhists hope that practitioners who dissolve the boundaries between self and other can cultivate an attitude of compassion toward others. Although Irigaray may seem to favor Buddhist philosophy over Western thought through her treatment of the body and breath, she believes that ethics is only possible through a combination of Buddhist and Western self. Irigaray believes that women have a special place within Buddhism. She argues that women are more attuned and inclined to sharing-a property that is prized by Buddhists. However, because they are committed to the idea that all beings engage in a relational way of being, Buddhists cannot recognize these special properties of the feminine and how women are better able to share [19]. Woman shares her breath. Either she remains at the level of vital breath, by giving oxygen to the fetus through her blood, or she shares spiritual breath. Sexuality and sex are often problems for Buddhist traditions because they represent cravings for a fixed idea of self, which in turn cause suffering. Irigaray uses sexuality to develop an ethical model because she believes sexual relations represent a genuine encounter between self and the other, which is the groundwork of ethics.

The Eight Garudhammas and other unequal gender-based Buddhist rules and teachings that disparage women have long raised serious doubts among Buddhist scholars and practitioners.

This inferiority issue not only affects the suffering group but also affects the other group. As a whole, the whole policy will be affected. Maybe, the rules were 
made by the monks in order to have a greater control over the nuns. This is only a suspicion and has no material evidence to support it. Having said so, it is not that the female birth was always considered as a negative one. In ancient India, when queen Malliqa of King Pasenadi of Kosala gave birth to a daughter, the king was a little dissatisfied. Then a blessed Buddhist convinced the king that a daughter may be better than a son. She can be a ruler, wise and virtuous and the son born from such a woman may well govern the kingdom. The stories from the Ekottarika Agama gives a view that female birth is a valuable asset, as itaffords an opportunity for Bhaddā Kaccānā and Bhaddā Kapilānī to walkthe path to liberation. Here I would like to quote one of the sayings of Buddha. He said that we should not believe blindly in anything. We should experiment the things by applying them in our lives and if we judge it to be right, then we should believe it is right, not just by listening to others and making decisions. That would be their decisions, not ours.

There are some other illustrations to show that Buddhism is not a sexist religion. Earlier limitations on attainment of Buddhahood by women were abolished in the Lotus Sutra which opened the direct path to enlightenment for women equally to men. Only in the Lotus Sutra do we read that a woman who embraces this sutra not only excels all other women but surpasses all men [20]. Women also have not given up. They are working relentlessly to show themselves equal to men, not inferior to them. One of the Buddhist monks has stated that she will work effortlessly to attain enlightenment if female form. I am quoting here the statement made by her. In the 20th Century Tenzin Palmo, a Tibe$\tan$ Buddhist nun in the Drukpa Lineage of the Kagyu School, stated I have made a vow to attain Enlightenment in the female form-no matter how many lifetimes it takes [21].

On reality grounds, we find that even in today's world, women are viewed as an asset of sexual pleasures by many men. They only think that women's role is to satisfy men's sexual desires. When we talk about Buddhism, we can find these kinds of views in some instances. Diana Paul writes Buddhism inherited a view of women whereby if they are not represented as mothers then they are portrayed as either lustful temptresses or as evil incarnate [22]. In the Anguttara Nikaya, Buddha tells future wives that they should be obedient to their husbands, please them, and not make them angry through their own desires, as well as get up before them and go to sleep after them. Furthermore, the Buddha offers advice to married women in the Anguttara Nikaya from the Pali (Theravada) canon, where he tells of seven types of wives-the first three types are destined for unhappiness, while the last four, as they are imbued with long term self-control, are destined to be happy. These latter wives are characterized as caretakers (motherly-wife), companions (friend-wife) and submissive (sister-wife and slave-wife) - the Buddha thus endorsed a variety of types of wives within marriage. From this also, we can say that females are subject to satisfy men, whatever regards that may be. Only then, they can be a good female being and a good human being. 


\section{Conclusion}

To conclude, we can say that the role of women in Buddhism is considered to be of less importance as compared to men. There is a very small room for women in Buddhism. Women have always been considered as a dependent asset and have been given lesser roles. But today's women have proved themselves to be extraordinary. They have proved to be well ahead of these rules. They have deserved a greater and an equal role as compared to men with their hard works. They have even outclassed men in many instances. We can see many women leaders leading their country as the head of the state these days. It takes time but I hope that one day this issue of inequality, inferiority and sexism will be no more seen in Buddhism and it will be an equal opportunity religion. Let us all wait for that great day. The main aim of this article was to highlight the issues faced by female Buddhist followers and get attention of the concerned authorities in this regard so that some improvements can be seen in the days to follow.

\section{References}

[1] Buddhist Studies (2008) Buddhism and Women: Position of Women at the Time of the Buddha. http://buddhanet.net/e-learning/history/position.htm

[2] Shih, H.C. (1992) Women in Zen Buddhism: Chinese Bhiksunis in the Chan Tradition. http://www.fjdh.cn/wumin/2009/04/06073472041.html

[3] Burke, A. (2014) Women in Zen Buddhism: Chinese Bhiksunis in the Chan Tradition.

https://jarconsian.wordpress.com/2014/02/05/women-in-zen-buddhism-chinese-bh iksunis-in-the-chan-tradition/

[4] Shaw, M. (1994) Passionate Enlightenment: Women in Tantric Buddhism. Princeton University Press, Princeton.

[5] Sutta, A. (2008) On Knowledge of Beginnings of Human Kind. 5-13

[6] Anālayo, B. (2013) The Legality of Bhikkhunī Ordination. Journal of Buddhist Ethics, 20, 316.

[7] Anālayo, B.J. (2013) The Gurudharma on Bhikṣuṇi Ordination in the Mūlasarvāstivāda Tradition. Journal of Buddhist Ethics, 20, 759.

[8] Kabilsingh, C. (1991) Thai Women in Buddhism. Berkeley.

[9] Anālayo, B. (2014) Karma and Female Birth. Journal of Buddhist Ethics, 21, 110 120.

[10] Cheng, W. (2014) Bhikkhunī Academy at Manelwatta Temple: A Case of CrossTradition Exchange. Journal of Buddhist Ethics, 21, 493.

[11] Goodwin, A.A. (2012) Right View, Red Rust, and White Bones: A Reexamination of Buddhist Teachings on Female Inferiority. Journal of Buddhist Ethics, 19, 198-343.

[12] Anālayo, B. (2015) The Cullavagga on Bhikkhunī Ordination. Journal of Buddhist Ethics, 22, 430.

[13] Battaglia, L.J. (2015) Becoming Bhikkhunī? Mae Chis and the Global Women's Ordination Movement. Journal of Buddhist Ethics, 30-45.

[14] Langenberg, A.P. (2014) Female Monastic Healing and Midwifery: A View from the Vinaya Tradition. Journal of Buddhist Ethics, 170-180.

[15] Mrozik, S. (2014) "We Love Our Nuns": Affective Dimensions of the Sri Lankan Bhikkhunī Revival. Journal of Buddhist Ethics, 58-72. 
[16] Ohnuma, R. (2013) Bad Nun: Thullanandā in Pāli Canonical and Commentarial Sources. Journal of Buddhist Ethics, 25-35.

[17] Pandita, V. (2014) Did the Buddha Correct Himself? Journal of Buddhist Ethics, 474-481.

[18] Swanepoel, E. (2014) Blossoms of the Dharma: The Contribution of Western Nuns in Transforming Gender Bias in Tibetan Buddhism. Journal of Buddhist Ethics, 573-583.

[19] Yeng, S. (2013) Irigaray's Meditations on the Duality of Sexuality in Buddhist Ethics. Journal of Buddhist Ethics, 210-219.

[20] Daisonin, N. (2015) The Enlightenment of Women. 56. https://anupadin.com

[21] Mackenzie, V. (1998) Cave in the Snow. Bloomsbury

[22] Diana, Y. and Paul, F.W. (1985) Traditional Views of Women: Women in Buddhism: Images of Feminine in Mahayana Tradition. University of California Press, Oakland.

Submit or recommend next manuscript to OALib Journal and we will provide best service for you:

- Publication frequency: Monthly

- 9 subject areas of science, technology and medicine

- Fair and rigorous peer-review system

- Fast publication process

- Article promotion in various social networking sites (LinkedIn, Facebook, Twitter, etc.)

- Maximum dissemination of your research work

Submit Your Paper Online: Click Here to Submit

Or Contact service@oalib.com 